SUBJECT AREAS:

ENVIRONMENTAL

CHEMISTRY

ENVIRONMENTAL MONITORING

Received

29 July 2014

Accepted

5 November 2014

Published

24 November 2014

Correspondence and requests for materials should be addressed to D.P.G. (gillikid@union. edu)

\section{Do freshwater mussel shells record} road-salt pollution?

\author{
Dane D. O’Neil \& David P. Gillikin \\ Department of Geology, Union College, Schenectady, NY, USA.
}

Road-salt pollution in streams in the Northeastern United States has become a major concern, but historical data are scarce. Freshwater bivalve shells have the ability to record past environmental information, and may act as archives of road-salt pollution. We sampled Elliptio complanata shells from four streams, as well as specimens collected in 1877 . Average $[\mathrm{Na} / \mathrm{Ca}]_{\text {shell }}$ was highest in modern shells from the stream with the highest sodium concentrations, and low in shells collected from this same stream in 1877 as well as in the shells from other streams, suggesting that $[\mathrm{Na} / \mathrm{Ca}]_{\text {shell }}$ serves as a proxy for road-salt pollution. We expected higher $[\mathrm{Na} / \mathrm{Ca}]_{\text {shell }}$ in winter and spring. However, high-resolution $[\mathrm{Na} / \mathrm{Ca}]_{\text {shell }}$ analyses along the growth axis of one shell did not reveal any clear subannual patterns, which could be the result of shell growth cessation in winter and/or during periods of high stream sodium concentrations. Therefore, bulk [Na/ $\mathrm{Ca}]_{\text {shell }}$ analysis from multiple shells can be used as a proxy of large changes in stream sodium concentrations, but high-resolution variations in stream sodium concentrations do not seem to be recorded in the shells.

$\mathrm{n}$ the Northeastern United States, streams are at risk from de-icing road-salt, which has already led to ecosystem degradation ${ }^{1-6}$. Warm season chloride concentrations in stream habitats may affect recruitment of endangered freshwater mussel species ${ }^{7}$ and has been found to influence mussel species richness ${ }^{8}$. Freshwater mussels are among the most endangered organisms in the United States with more than $70 \%$ of species being listed as endangered, threatened, or of special concern ${ }^{9,10}$. De-icing road-salt is used in northern US states during winter months to prevent ice buildup on roads and its use has more than tripled since the 1960 ' $\mathrm{s}^{11}$; however, runoff in the late winter and spring lead to large increases in $\mathrm{NaCl}$ within freshwater stream systems $\mathrm{s}^{2,3}$ and, depending on the ground permeability, can also affect groundwater reservoirs ${ }^{3,12}$. As much as 12 million tons of road-salt have been used per year in the United States, with Massachusetts (19.94 tons/lane-mi/yr) and New York (16.6 tons/lane-mi./yr) reporting some of the highest annual amounts ${ }^{13}$.

The increased $\mathrm{NaCl}$ causes a direct increase in stream salinity to which most freshwater organisms are unaccustomed; however, the increase also induces soil ion exchange of some heavier metals ( $\mathrm{Zn}$, Cd), as well as increases the mobility of $\mathrm{H}^{+}$ions resulting in acidification on small scales in some systems ${ }^{12}$. Furthermore, the effect of road-salt within freshwater ecosystems can vary depending on the surrounding ground permeability (impervious surfaces), which would be very high in urban areas and lower in rural areas (mainly a function of the number of roads) ${ }^{4}$. Monitoring of stream $\mathrm{Na}^{+}$and $\mathrm{Cl}^{-}$ion concentrations can often be an expensive endeavor and cannot be extended into the past. Extending these records into the past would be valuable to ascertain if the pollution is short-lived (e.g., only after snowy winters) or chronic (i.e., year-round high concentrations) and for how long it has persisted in order to gain insight on the potential impact of the pollution and to predict future pollution trajectories (cf. 3).

Freshwater bivalve shells have been successfully used as temporally resolved archives of water chemistry ${ }^{14-17}$. Freshwater mussels are common in many streams, and although they have declined due to anthropogenic pressures in the past decades, there are still some cosmopolitan species, such as Elliptio complanata ${ }^{9,18}$, which could be sacrificed as archives of stream chemistry.

Considering that road-salt sales and application started to rise in the 1960 's ${ }^{11}$, we hypothesize that bivalves growing in urbanized watersheds with high impervious surface cover will have high shell sodium content (expressed as $[\mathrm{Na} / \mathrm{Ca}]_{\text {shell }}$ ) compared to shells that grew in these same streams before the 1900 's. Moreover, we hypothesize that shells growing in urbanized streams with high dissolved sodium concentrations will have higher $[\mathrm{Na} / \mathrm{Ca}]_{\text {shell }}$ compared to shells from more pristine streams with lower sodium concentrations. The overall objective of this study is to determine if the freshwater bivalve Elliptio complanata records stream sodium concentrations within their aragonite shells. We examined shells from several streams that ranged from nearly pristine to fully urban in order to cover a large sodium concentration gradient. 


\section{Methods}

Elliptio complanata specimens (non-endangered freshwater mussels) were collected in May 2008 from four streams (all on public land or private land open to the public) in Dutchess County, New York (USA): the Casperkill (Ck), Fallkill (Fk), Sawkill (Sk), and Crum Elbow (Ce) under license of the New York State Environmental Conservation Department. Mollusks are not covered under the ethics committees at Vassar College nor Union College, but were treated as humanely as possible during collection. In addition to published water chemistry data from these streams $\mathrm{s}^{4,5}$, water samples were taken from each stream on three separate days within a two-week period in late spring 2008 (June 9, 12, and 16). Water was sampled as described in Cunningham et al. ${ }^{4}$. Briefly, samples were filtered through $0.2 \mu \mathrm{m}$ PES syringe filters (Sartorius, 16532-Q) in the field into clean $2 \mathrm{~mL}$ ion chromatography sample vials. Samples were stored at $4^{\circ} \mathrm{C}$ and analyzed for sodium and chloride concentrations in duplicate within two days on a Dionex ICS-3000 Dual RFIC System ion chromatograph at Vassar College.

Three shells were selected from each stream to represent the broadest range of growth length to test for size and/ or ontogenic effects. In addition, two historical $E$. complanata shells collected from the Casperkill at Vassar College in 1877 (courtesy of the University of Michigan Museum of Zoology, Ck-1877 and Ck-1877 \#2) were also included in this study, bringing the total number of shells analyzed to 14 . Shell height ranged from 2.49 to $4.60 \mathrm{~cm}$ (average $=3.70 \pm 0.60 \mathrm{~cm}$ ) and shell length ranged from 4.35 to $8.53 \mathrm{~cm}$ (average $=6.92 \pm 1.17 \mathrm{~cm}$ ). Sections of the shells were cut with a diamond saw along the axis of maximal growth from umbo to commissure, rinsed with deionized water, and air-dried.

Shells were analyzed using Union College's Perkin Elmer Elan 6100 DRC Inductively Coupled Plasma Mass Spectrometer and a CETAC LSX-213 frequency quintupled Nd:YAG laser $(\lambda=213 \mathrm{~nm})$, using the USGS MACS 1 and 3 carbonate standards (ThO/Th ratios were less than $0.4 \%$; monitored using the NIST 612 glass standard). Details of the LA-ICP-MS operating conditions can be found in Gillikin and Dehairs ${ }^{19}$. $\mathrm{Na}^{23}$ and $\mathrm{Ca}^{43}$ were monitored and helium was used as the carrier gas $(600 \mathrm{~mL} / \mathrm{min})$, which was mixed with argon after the ablation cell $(840 \mathrm{~mL} / \mathrm{min})$. A spot size of $50 \mu \mathrm{m}$ was used with the laser set at $10 \mathrm{~Hz}$ and 600 burst counts. A $15 \mathrm{~s}$ pre-ablation was used for gas blank corrections (i.e., the shutter was closed). The USGS standard MACS-3 was used for calibration and MACS-1 was used to check the calibration, which suggests a robust LA-ICP-MS calibration and good reproducibility $([\mathrm{Na}]=36.8 \pm 4.9 \mathrm{ppm}($ or $\mathrm{Na} / \mathrm{Ca}=0.16 \pm 0.02 \mathrm{mmol} / \mathrm{mol}), \mathrm{n}=27$ on nine analytical days; recommended value $=36.5 \pm 21.4 \mathrm{ppm}$ (Stephen Wilson, USGS, personal communication, 2012). Moreover, one shell (Ck-1) was analyzed along adjacent transects on two analytical sessions separated by more than 6 months and produced indistinguishable data (transect $1=6.82 \pm 0.56 \mathrm{mmol} / \mathrm{mol}$; transect $2=$ $6.71 \pm 0.59 \mathrm{mmol} / \mathrm{mol} ; \mathrm{n}=25$ for each). Note that the NIST glasses $(610$ and 612$)$ have very high $\mathrm{Na}$ concentrations so should not be used for calibration. The shells were analyzed near the umbo region in the nacreous layer, starting near the inside of the shell (most recent shell precipitated), and moving outwards covering the most recent 2 to 5 years of growth (Fig. 1); these data were then averaged to produce a 'bulk shell' measurement (see also Ref. 19). One sample (Ck-1) was analyzed along the prismatic layer, starting at the commissure and moving towards the umbo (Fig. 1) (see Carroll and Romane ${ }^{17}$ for details on this sampling protocol). The valve height of this shell was $6.5 \mathrm{~cm}$ in total, but we sampled only to $2.1 \mathrm{~cm}$ from the commissure. Takesue et al..$^{21}$ found that $[\mathrm{Na} / \mathrm{Ca}]_{\text {shell }}$ ratios were not different between right and left valves, nor between prismatic and nacreous layers of aragonitic marine shells, therefore we assumed it is reasonable to ignore these as variables. Carroll and Romanek $^{17}$ found similar results for other elements in the same freshwater mussel species used in this study, E. complanata. In the prismatic layer, the laser was shot 150 microns from the outside surface of the shell, and 150 microns from each other. Data were reduced using GeoPro software (CETAC) as described in Gillikin and Dehairs ${ }^{19}$.

Internal and external growth lines were visually determined using a binocular microscope after removing part of the periostracum and polishing the cross section surface. To validate growth lines as annual markers, shell carbonate from shell Ck-1 was drilled along the prismatic layer every 350 microns using a New Wave Micromill and 300-micron drill bit. Carbonate powders $(\sim 100 \mu \mathrm{g})$ were reacted with phosphoric acid at $70^{\circ} \mathrm{C}$ for at least 3 hours in a ThermoScientific Gas Bench II coupled to a ThermoScientific Delta Advantage at Union College. Data were corrected using the regression method with LSVEC $\left(\delta^{18} \mathrm{O}=-26.7 \%\right)$, NBS-18 $\left(\delta^{18} \mathrm{O}=-23.2 \%\right.$ ), and NBS-19 $\left(\delta^{18} \mathrm{O}=-2.2 \%\right.$ ) as standards, providing a precision of $< \pm 0.1 \%$. Statistical tests were carried out using SigmaStat after testing for normality and equal variance.

\section{Results}

Water data illustrate the high salt concentrations in the Casperkill, as reported in Cunningham et al. ${ }^{4}$. The Casperkill had a late spring $\mathrm{Na}$ concentration of $75.1 \pm 16.1 \mathrm{mg} / \mathrm{L}$, while the Fallkill, Crum Elbow and Sawkill all had late spring $\mathrm{Na}$ concentrations of less than $25 \mathrm{mg} /$ $\mathrm{L}(\mathrm{Fk}=21.8 \pm 1.9, \mathrm{Ce}=20.7 \pm 3.8 ; \mathrm{Sk}=19.8 \pm 1.9)$. The Casperkill had significantly higher sodium than the other streams (ANOVA, Tukey HSD Test, $\mathrm{p}<0.01$ ), while the three other streams were not statistically different from one another. The $\mathrm{Na}$ concentrations persist year-round (see Refs. 4 and 5; these papers report chloride concentrations, which are strongly correlated to $[\mathrm{Na}]$ in these streams with the relationship: $\mathrm{Na}(\mathrm{mg} / \mathrm{L})=0.674 * \mathrm{Cl}(\mathrm{mg} / \mathrm{L})+0.732 ; \mathrm{r}^{2}=$ $0.992, \mathrm{n}=12$ ).

The highest average $[\mathrm{Na} / \mathrm{Ca}]_{\text {shell }}$ was for mussel shells that had lived in the stream with the highest $\mathrm{Na}$ content (Figs. $2 \& 3$ ). The modern $\mathrm{Ck}$ shells showed the highest average $[\mathrm{Na} / \mathrm{Ca}]_{\text {shell }}$ of $7.62 \pm$ $0.54 \mathrm{mmol} / \mathrm{mol}(\mathrm{n}=3 \mathrm{shells})$, with the Ce $(6.68 \pm 0.62 \mathrm{mmol} / \mathrm{mol}$, $\mathrm{n}=3$ shells $), \mathrm{Fk}(6.64 \pm 0.49 \mathrm{mmol} / \mathrm{mol}, \mathrm{n}=3$ shells $)$, and Sk $(6.78$ $\pm 0.58 \mathrm{mmol} / \mathrm{mol}, \mathrm{n}=3$ shells) shells exhibiting similar values (Fig. 3). The $[\mathrm{Na} / \mathrm{Ca}]_{\text {shell }}$ of the $\mathrm{Ck}$ shells were significantly higher than shells from the other streams (one way ANOVA on raw data, $p$ $<0.001$; pairwise comparison using Holm-Sidak method, $p \gg$ 0.0001 for each), whereas the shells from the other three streams were not significantly different from one another (pairwise comparison using Holm-Sidak method, $p=0.09$ for each). The $1877 \mathrm{Ck}$ shells had significantly lower $\mathrm{Na} / \mathrm{Ca}$ ratios $(\mathrm{Ck}-1877=6.12 \pm$ $0.32 \mathrm{mmol} / \mathrm{mol}$; Ck-1877\#2 = $6.25 \pm 0.77 \mathrm{mmol} / \mathrm{mol}$; Fig. 2) than the modern Ck shells (t-test, $p<0.001$ ).

The Ck-1 shell analyzed in high-resolution along the prismatic layer did not show a clear annual pattern in $\mathrm{Na} / \mathrm{Ca}$ values (Fig. 4). Significant drops in $\mathrm{Na} / \mathrm{Ca}$ ratios occur near the commissure, as well as along the first three growth lines closest to the commissure. Oxygen-isotope ratio data from shell $\mathrm{Ck}-1$ ranged between $-8.4 \%$ and $-6.5 \%$, with a sinusoidal pattern (Fig. 4). Growth lines matched with most $\delta^{18} \mathrm{O}$ maxima.

\section{Discussion}

'Bulk-shell' analysis of bivalves in freshwater systems can provide an insight into the level of sodium within the stream in which the bivalves lived. Shells from the stream with the highest sodium content (Casperkill) show the highest $[\mathrm{Na} / \mathrm{Ca}]_{\text {shell }}$ (modern Casperkill shells; Fig. 3). Shells from the other streams, all of which had lower sodium content than the Casperkill, consequently had lower $[\mathrm{Na} /$

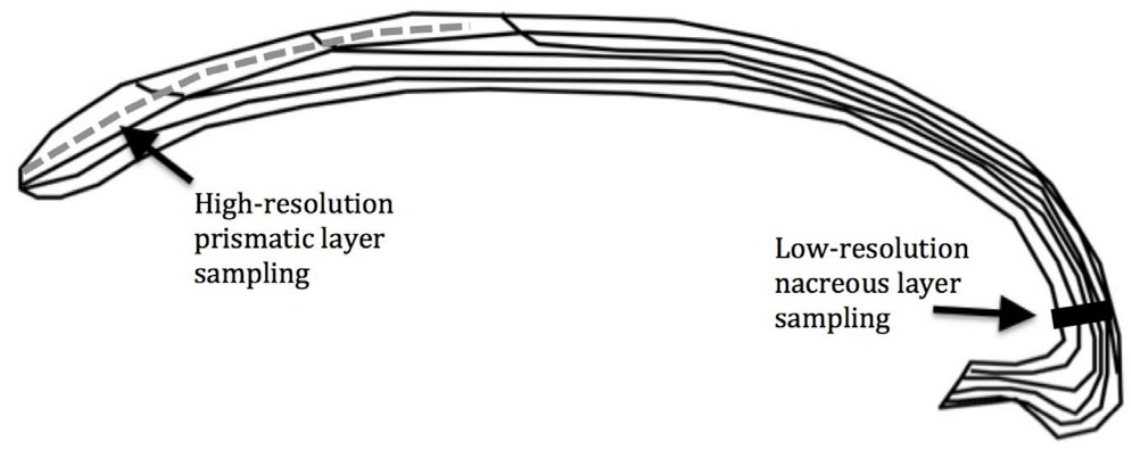

Figure 1 Schematic of a shell cross-section (growth is from right to left). All 14 shells were sampled for low-resolution 'bulk-shell' Na/Ca values in the nacreous layer near the umbo (thick black line); 9 to 43 LA-ICP-MS shots were averaged per shell (covering $2-5$ years of growth). One shell from the Casperkill (Ck-1) was sampled in the prismatic layer (dashed grey line) to provide a high-resolution profile of shell $\mathrm{Na} / \mathrm{Ca}$ values. 


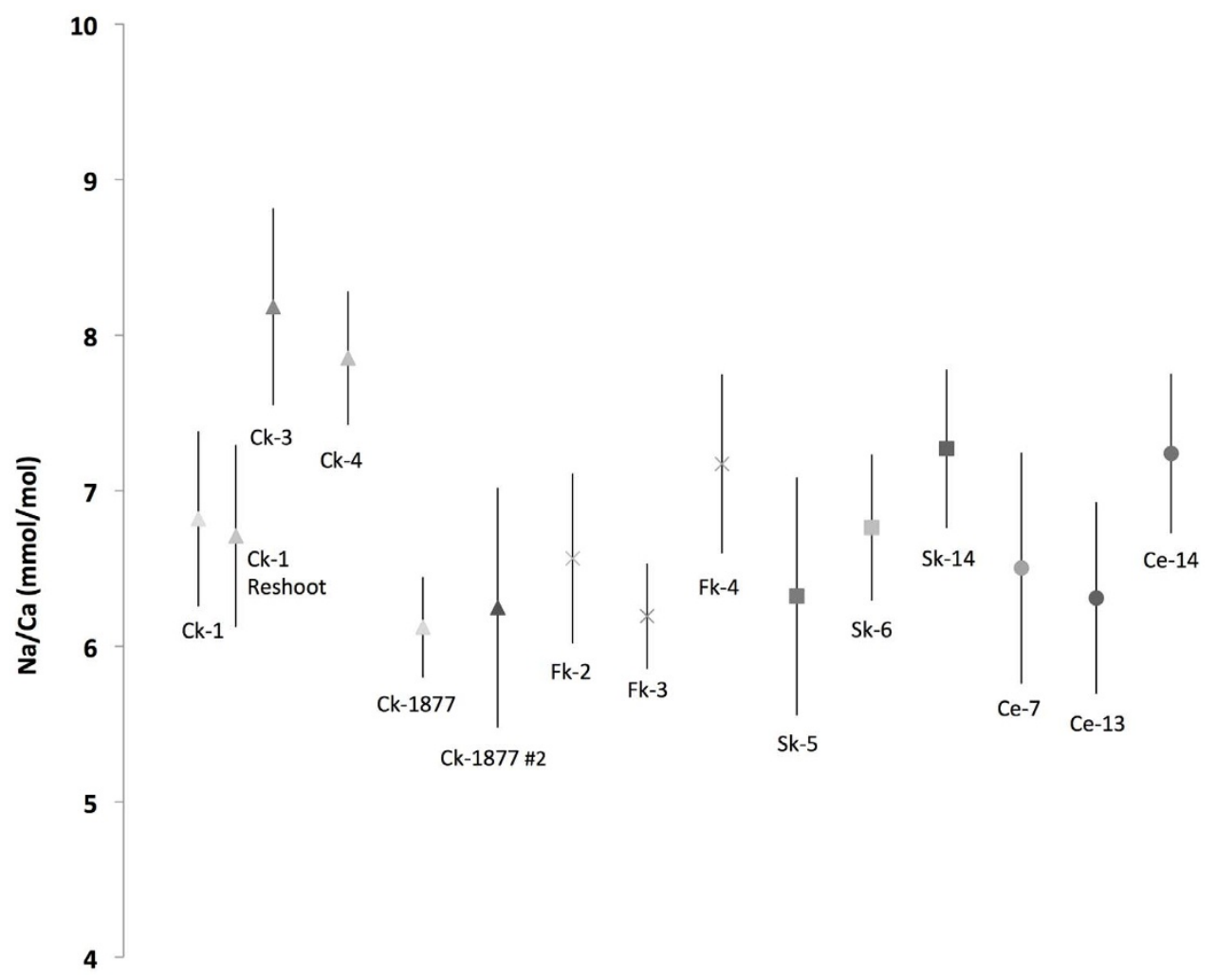

Figure $2 \mid$ Average $\mathrm{Na} / \mathrm{Ca}$ ratio $(\mathrm{mmol} / \mathrm{mol})$ for 14 shells analyzed $( \pm 1 \sigma)$. The shells are organized in order of stream, from the highest $[\mathrm{Na}]$ value (Casperkill, Ck) to the lowest (Crum Elbow, Ce); the Fallkill (Fk) and Sawkill (Sk) have intermediate Na concentrations. Shells collected from the Casperkill in 1877 (Ck-1877) are also shown. River water Na concentrations were: $\mathrm{Ck}=75.1 \pm 16.1 \mathrm{mg} / \mathrm{L}, \mathrm{Fk}=21.8 \pm 1.9 \mathrm{mg} / \mathrm{L}, \mathrm{Ce}=20.7 \pm 3.8 \mathrm{mg} / \mathrm{L}$, $\mathrm{Sk}=19.8 \pm 1.9 \mathrm{mg} / \mathrm{L}$

$\mathrm{Ca}]_{\text {shell }}$ concentrations than the Casperkill shells. The variations between each shell within a site are relatively high, regardless of the sodium content of the stream (Figs. $2 \& 3$ ), so several shells should be pooled to estimate past stream sodium concentrations. We are uncertain why the $\mathrm{Ck}-1$ shell had such a lower average $\mathrm{Na}$ / Ca ratio when compared with the other two shells from this stream (Fig. 2). Replicate analysis on this shell confirmed the lower ratio (see methods and Fig. 2). The Ck-1 shell is the largest of the modern Ck shells (shell length Ck-1 $=8.53 \mathrm{~cm}, \mathrm{Ck}-3=8.13 \mathrm{~cm}, \mathrm{Ck}-4=$ $8.05 \mathrm{~cm}$ ), which could suggest a size effect on $\mathrm{Na}$ incorporation, however, there are larger size differences between shells from other streams without any trend in shell $\mathrm{Na} / \mathrm{Ca}$ ratios. There is also no clear relationship between shell size and $\mathrm{Na} / \mathrm{Ca}$ ratio $\left(\mathrm{r}^{2}=0.04\right)$, nor any trend through ontogeny (Fig. 4 and low resolution data from other shells). Therefore, only multiple shells analyzed in bulk from the umbo region should be used to develop a record of past stream sodium concentrations.

There is a large difference between the sodium content of the modern and ancient (1877) shells taken from the Casperkill stream. This suggests that environmental conditions were different in 1877 than the present-day and that shells do indeed track large changes in stream Na concentrations. Road-salt usage in the Northeast USA did not become widely popular until the 1960 's ${ }^{11}$. The 1877 Casperkill shell data strongly suggest that anthropogenic road-salt pollution is the most parsimonious hypothesis to explain the high sodium concentrations in this stream. This further illustrates that freshwater bivalve shells can be used to demonstrate that sodium pollution is a modern phenomenon.

In order to determine if high-resolution intra-shell $\mathrm{Na} / \mathrm{Ca}$ data can be used to track subannual stream Na variability, an age model needs to be developed to align $\mathrm{Na} / \mathrm{Ca}$ data with time. Shell oxygen-isotope ratios (expressed as $\delta^{18} \mathrm{O}$ values) are known to exhibit clear annual cyclicity in temperate regions such as New York State (see Ref. 22). The $\delta^{18} \mathrm{O}$ values of shell carbonate are dependent on both the $\delta^{18} \mathrm{O}$ values of water and water temperature ${ }^{23}$. With the large seasonal variation in temperature in New York State, we expect temperature to exert the dominant control on shell $\delta^{18} \mathrm{O}$ values, similar to Wurster and Patterson ${ }^{22}$ (see Ref. 24). Considering the inverse relationship between shell $\delta^{18} \mathrm{O}$ values and water temperature ${ }^{23}$, maximum shell $\delta^{18} \mathrm{O}$ values should correspond to winter or late fall when shell growth stops and growth lines form. Most growth lines match up with maximum $\delta^{18} \mathrm{O}$ values (Fig. 4 ), which provides confidence with the position of winter marks in these shells and confirm the work of Veinott and Cornett ${ }^{25}$. When high-resolution $\mathrm{Na} / \mathrm{Ca}$ analysis was completed on the prismatic layer of shell $\mathrm{Ck}-1$ and overlain with the oxygen-isotope ratio profile (based on distance along the shell) no clear annual signal could be found in the $\mathrm{Na} / \mathrm{Ca}$ data (Fig. 4). We expected high $[\mathrm{Na} / \mathrm{Ca}]_{\text {shell }}$ values in the winter/spring, when snowmelt and stream [Na] is high, and lower values in the summer/fall when stream [Na] is low, as has been shown in several studies ${ }^{2,4}$, but no such relationship was observed in Ck-1. Contrary to our expectations, a decrease in $[\mathrm{Na} / \mathrm{Ca}]_{\text {shell }}$ ratios in the spring of some years was observed (Fig. 4). This may be due to the combination of multiple variables; first, bivalves often shut down shell production in the winter when temperatures drop below $12^{\circ} \mathrm{C}^{23}$ and stream $[\mathrm{Na}]$ would not be recorded during this time; second, shell production rates in bivalves often slow as the organisms grow older (e.g., Refs. 20 and 26) which reduces seasonal shell growth, as older bivalves will stop shell precipitation earlier in the winter and restart precipitation later in the spring, resulting in a longer growth cessation in older specimens ${ }^{26,27}$. However if this were the case, we would expect to see a diminishing amplitude in shell $\delta^{18} \mathrm{O}$ values as the bivalve ages, which is not present (Fig. 4). The increased flux of sodium into the streams can be at such a high rate in the early spring (when salt runoff from melting 


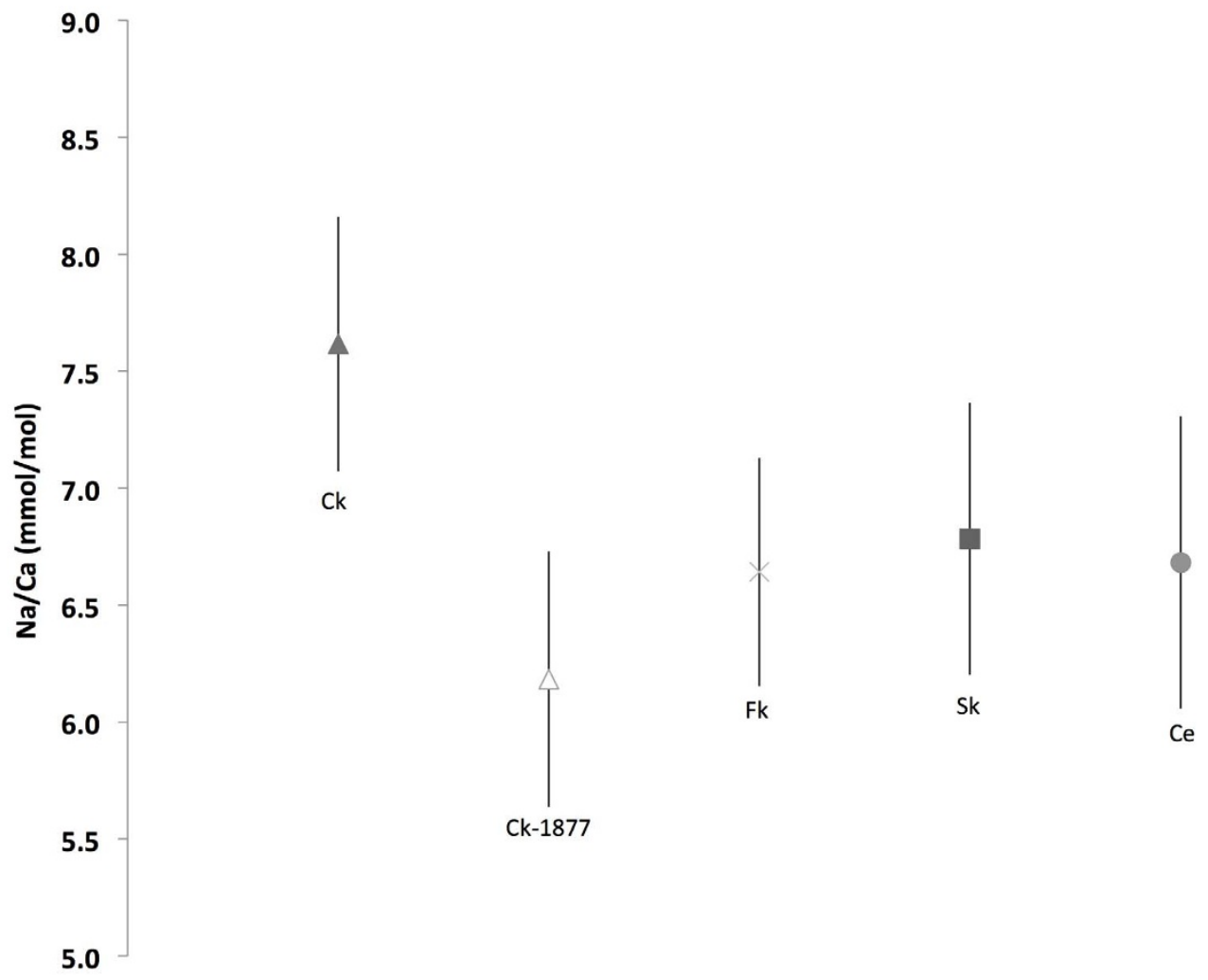

Figure $3 \mid$ The average $\mathrm{Na} / \mathrm{Ca}$ ratio $(\mathrm{mmol} / \mathrm{mol})$ of all modern shells $(\mathrm{n}=3$ shells for each) and the two shells from the Casperkill collected in 1877 $( \pm 1 \sigma)$, organized by stream $\mathrm{Na}$ concentration (from high to low). The Ck shells have significantly higher $\mathrm{Na} / \mathrm{Ca}$ ratios $(p<0.001)$ compared with the other modern shells and are significantly higher than the Casperkill shells collected in $1877(p<0.001)$. Sample codes as in Fig. 2. River water Na concentrations were: $\mathrm{Ck}=75.1 \pm 16.1 \mathrm{mg} / \mathrm{L}, \mathrm{Fk}=21.8 \pm 1.9 \mathrm{mg} / \mathrm{L}, \mathrm{Ce}=20.7 \pm 3.8 \mathrm{mg} / \mathrm{L}, \mathrm{Sk}=19.8 \pm 1.9 \mathrm{mg} / \mathrm{L}$.

snow would presumably be highest ${ }^{2,4}$ ) that it may adversely affect the bivalve, causing it to stop or slow shell production during these times. Several studies have shown that increased stream sodium concentrations adversely affects freshwater bivalves ${ }^{7,8}$. There is a slight $[\mathrm{Na} /$ $\mathrm{Ca}]_{\text {shell }}$ decrease through time in shell Ck-1 (Fig. 4), which is likely also not an environmental signal considering road salt usage has not declined recently ${ }^{3}$. Data from nearby Wappingers Creek show a steady increase in stream chloride between the year 2000 and $2005^{3}$ and data from the Casperkill from 2006 and 2007 do not show any decrease in salt concentrations ${ }^{5}$. Considering the lack of a seasonal signal, this proxy can probably only be applied to large, persistent changes in stream sodium concentrations, but cannot track subtle changes (i.e., sub-annual variability). Interestingly, the $\mathrm{Na} / \mathrm{Ca}$ ratios of the prismatic shells layer of $\mathrm{Ck}-1$ match the values from the other two modern Ck shells. Future studies should investigate the prismatic layer of the shell as a proxy of stream [Na]. Although other studies did not find large differences between elements in the different shell layers of this species ${ }^{17}$, perhaps there is less inter-specimen variability in $\mathrm{Na} / \mathrm{Ca}$ if the outer prismatic layer is used.

Although trace element profiles of bivalve shells have been used as environmental proxies, both in the past and the present (e.g., Refs. 15, 28 , and 29), few have concentrated on the applications of sodium as a proxy. Rosenthal and $\mathrm{Kat}^{30}$ presented data from freshwater mollusk shells (gastropods) and reported that $\mathrm{Na} / \mathrm{Ca}$ ratios remain constant independent of water chemistry. Likewise, Lee and Wilson ${ }^{28}$ reported constant $\mathrm{Na} / \mathrm{Ca}$ ratios in freshwater mussel shell aragonite despite variable stream water concentrations. However, Findlater et al. ${ }^{31}$ compared modern freshwater mussels with aragonite marine clam shells and found that the freshwater shells generally had lower $\mathrm{Na}$ concentrations, suggesting an environmental control on shell $\mathrm{Na}$. Moreover, Rucker and Valentine ${ }^{32}$ found that sodium concentrations in shells of the oyster Crassostrea virginica correlated with salinity, and Lorens and Bender ${ }^{33}$ reported similar results for the common marine mussel Mytilus edulis. Other calcifying organisms also seem to record salinity in their carbonate skeletons; Wit et al. ${ }^{34}$ recently reported that $\mathrm{Na} / \mathrm{Ca}$ ratios can be used as a paleosalinity proxy in foraminiferal calcite based on a laboratory culture study with a salinity range of 8.6 units. There seem to be contrasting reports regarding controls on coral skeletal Na/Ca ratios (see Refs. 35 and 36). These other studies, along with our own, highlight the potential of $\mathrm{Na} / \mathrm{Ca}$ in biogenic carbonates as an environmental proxy, but also suggest that this proxy may be species specific and should not be used without controlled analyses on each species studied.

The method of uptake and location of sodium into the shell itself is unclear. Two possible suggestions are that: 1) the sodium ion replaces calcium ions or otherwise fits within the $\mathrm{CaCO}_{3}$ lattice, or 2) the sodium is taken up within the organic matrix of the shell. The principal mechanism for the incorporation of $\mathrm{Na}$ into biogenic marine calcium carbonate has been suggested to be ion incorporation into lattice defects and distortions and/or ion adsorption $^{36,37}$. Ion incorporation can vary between aragonitic and calcitic shells as well; it is suggested that $\mathrm{Na}$ can more easily be incorporated in the organic matrix of the shell and not substitute for calcium in calcite; however, $\mathrm{Na}$ will substitute for calcium in aragonite $^{38}$. Nevertheless, Rosenthal and $\mathrm{Kat}^{30}$ report that $\mathrm{Na}$ is not bound in the aragonite lattice in gastropod shells. Since we are dealing with one species (Elliptio complanata), and only used livekilled specimens, the method of $\mathrm{Na}$ uptake should not affect our results, assuming that individuals of this species incorporate sodium into their shells in a similar manner and that diagenesis of carbonate-bound organics or carbonate has not taken place. Likewise, the carbonate-bound organic matrix in museum preserved shells (dry stored) should also be preserved for some time (see Ref. 39). Therefore, if shell $\mathrm{Na}$ is stored in shell organic 


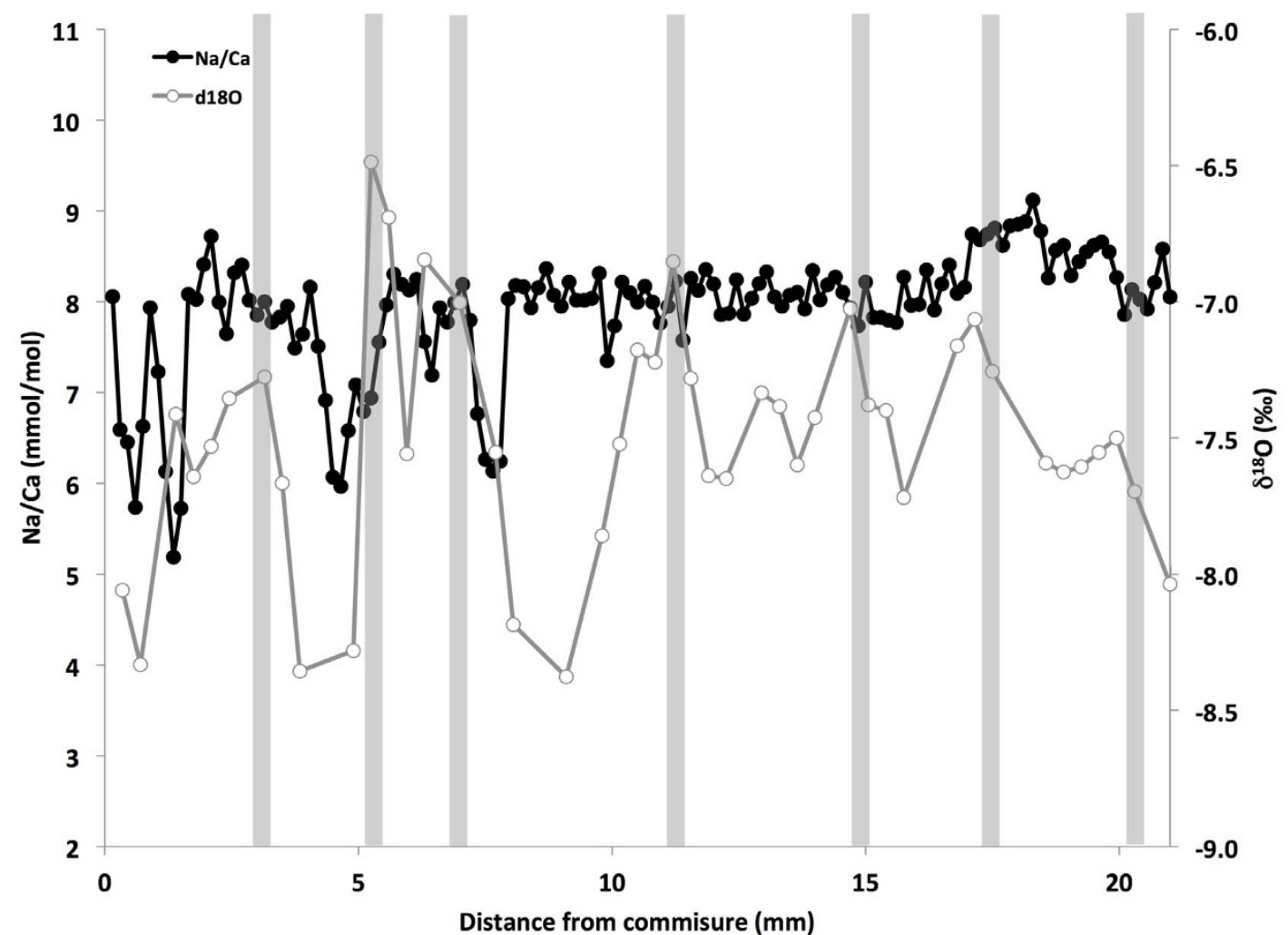

Figure $4 \mid$ High-resolution $\mathrm{Na} / \mathrm{Ca}$ and $\delta^{18} \mathrm{O}$ values along the prismatic layer in shell $\mathrm{Ck}-1$. Annual growth lines are represented by vertical bars. Growth lines occur at maximum $\delta^{18} \mathrm{O}$ values (winter) confirming they are annual winter growth checks. Maxima $\delta^{18} \mathrm{O}$ values at 1.4 and $13 \mathrm{~mm}$ are assumed to be annual with indistinct growth lines. Shell growth and thus time is from right to left. Analytical precision is better than $\pm 0.02 \mathrm{mmol} / \mathrm{mol}$ for Na/Ca ratios and $\pm 0.1 \%$ for $\delta^{18} \mathrm{O}$ values.

matter, museum archived shells should provide a record of past stream $\mathrm{Na}$ concentrations as demonstrated by this study.

\section{Conclusions}

Three main conclusions can be drawn from this research: (1) lowresolution analysis of $\mathrm{Na} / \mathrm{Ca}$ in freshwater bivalve shells can record persistent sodium pollution in streams; (2) pre-roadsalt shells from the 1800's have lower $\mathrm{Na} / \mathrm{Ca}$ than shells taken from the same stream today, suggesting an increase in salt content in streams as a result of anthropogenic road-salt use in the Northeastern USA; (3) high-resolution analysis of sodium in freshwater bivalve shells is not reliable for tracking seasonal fluxes in stream salt content (based on one shell analyzed in this study).

1. Forman, R. T. T. \& Alexander, L. E. Roads and their major ecological effects. Annu. Rev. Ecol. Syst. 29, 207-231 (1998).

2. Kaushal, S. S. et al. Increased salinization of fresh water in the Northeastern United States. P. Natl. Acad. Sci. USA 102, 13517-13520 (2005).

3. Kelly, V. R. et al. Long-term sodium chloride retention in a rural watershed: legacy effects of road salt on streamwater concentration. Environ. Sci. Techn. 42, 410-415 (2008)

4. Cunningham, M. A. et al. The Suburban Stream Syndrome: Evaluating Land use and Stream Impairments in the Suburbs. Phys. Geogr. 30, 269-284 (2009).

5. Cunningham, M. A. et al. Influence of open space on water quality in an urban stream. Phys. Geogr. 31, 336-356 (2010).

6. Canedo-Arguelles, M. et al. Salinisation of rivers: An urgent ecological issue. Environ. Pollut. 173, 157-167 (2013).

7. Todd, A. K. \& Kaltenecker, M. G. Warm season chloride concentrations in stream habitats of freshwater mussel species at risk. Environ. Poll. 171, 199-206 (2012).

8. Metcalfe-Smith, J. L., Di Maio, J., Staton, S. K. \& DeSolla, S. R. Status of the freshwater mussel communities of the Sydenham River, Ontario, Canada. Am. Midl. Nat. 150, 37-50 (2003).

9. Williams, J. D., Warren, M. L., Cummings, K. S., Harris, J. L. \& Neves, R. J. Conservation Status of Freshwater Mussels of the United States and Canada. Fisheries 18, 6-22 (1993).
10. Stokstad, E. Nearly buried, mussels get a helping hand. Science 338, 876-878 (2012).

11. Jackson, R. B. \& Jobbágy, E. G. From icy roads to salty streams. P. Natl. Acad. Sci. USA 102, 14487-14488 (2005).

12. Löfgren, $S$. The chemical effects of deicing salt on soil and stream water of five catchments in southeast Sweden. Water Air Soil Poll. 130, 863-868 (2001).

13. Godwin, K. S., Hafner, S. D. \& Buff, M. F. Long-term trends in sodium and chloride in the Mohawk River, New York: the effect of fifty years of road-salt application. Environ. Poll. 124, 273-281 (2003).

14. Markich, S. J., Jeffree, R. A. \& Burke, P. T. Freshwater bivalve shells as archival indicators of metal pollution from a copper-uranium mine in tropical northern Australia. Environ. Sci. Technol. 36, 821-832 (2002).

15. Ravera, O., Cenci, R., Beone, G. M., Dantas, M. \& Lodigiani, P. Trace Element concentrations in freshwater mussels and macrophytes as related to those in their environment. J. Limnol. 62, 61-70 (2003).

16. Brenner, M., Smoak, J. M., Leeper, D. A., Streubert, M. \& Baker, S. M. Radium-226 accumulation in Florida freshwater mussels. Limnol. Oceanogr. 52, 1614-1623 (2007).

17. Carroll, M. \& Romanek, C. S. Shell layer variation in trace element concentration for the bivalve, Elliptio complanata. Geo-Mar. Lett. 28, 369-381 (2008).

18. Strayer, D. L. \& Jirka, K. J. The Pearly Mussels of New York State [1-113] (N. Y. State Mus. Mem., 26 1997).

19. Gillikin, D. P. \& Dehairs, F. Uranium in aragonitic marine bivalve shells. Palaeogeogr. Palaeoclim. Palaeoecol. 373, 60-65 (2013).

20. Gillikin, D. P. et al. Assessing the reproducibility and reliability of estuarine bivalve shells (Saxidomus giganteus) for sea surface temperature reconstruction: implications for paleoclimate studies. Palaeogeogr. Palaeoclim. Palaeoecol. 228, $70-85$ (2005).

21. Takesue, R. K., Bacon, C. R. \& Thompson, J. K. Influences of organic matter and calcification rate on trace elements in aragonitic estuarine bivalve shells. Geochim. Cosmochim. Acta 72, 5431-5445 (2008).

22. Wurster, C. M. \& Patterson, W. P. Stable oxygen and carbon isotope values recovered from lacustrine freshwater mollusks: Paleoclimatic implications for subweekly temperature records. J. Paleolimnol. 26, 205-218 (2001).

23. Dettman, D. L., Reische, A. K. \& Lohmann, K. C. Controls on the stable isotope composition of seasonal growth bands in aragonitic freshwater bivalves (unionidae). Geochim. Cosmochim. Ac. 63, 1049-1057 (1999).

24. Gillikin, D. P., Hutchinson, K. \& Kumai, Y. Ontogenic increase of metabolic carbon in freshwater mussel shells (Pyganodon cataracta). J. Geophys. Res.Biogeosci. 114, G01007, doi:10.1029/2008JG000829 (2009). 
25. Veinott, G. I. \& Cornett, R. J. Identification of annually produced opaque bands in the shell of the freshwater mussel Elliptio complanata using the seasonal cycle of $\delta^{18}$ O. Can. J. Fish. Aquat. Sci. 53, 372-379 (1995).

26. Goodwin, D. H., Schoöne, B. R. \& Dettman, D. L. Resolution and fidelity of oxygen isotopes as paleotemperature proxies in bivalve mollusk shells: models and observations. Palaios 18, 110-125 (2003).

27. Schöne, B. R., Tanabe, K., Dettman, D. L. \& Sato, S. Environmental controls on shell growth rates and $\delta^{18} \mathrm{O}$ of the shallow-marine bivalve mollusk Phacosoma japonicum in Japan. Mar. Bio. 142, 473-485 (2003).

28. Lee, F. G. \& Wilson, W. Use of chemical composition of freshwater clamshells as indicators of paleohydrologic conditions. Ecology 50, 990-997 (1969).

29. Gillikin, D. P. et al. Barium uptake into the shells of the common mussel (Mytilus edulis) and the potential for estuarine paleo-chemistry reconstruction. Geochim. Cosmochim. Ac. 70, 395-407 (2006).

30. Rosenthal, Y. \& Katz, A. The applicability of trace elements in freshwater shells for paleogeochemical studies. Chem. Geol. 78, 65-76 (1989).

31. Findlater, G., Shelton, A., Rolin, T. \& Andrews, J. Sodium and strontium in mollusc shells: preservation, palaeosalinity and palaeotemperature of the Middle Pleistocene of eastern England. P. Geologist. Assoc. 125, 14-19 (2014).

32. Rucker, J. B. \& Valentine, J. W. Salinity response of trace elements concentration in Crassostrea virginica. Nature 190, 1099-1100 (1961).

33. Lorens, R. B. \& Bender, M. L. The impact of solution chemistry on Mytilus edulis calcite and aragonite. Geochim. Cosmochim. Acta 44, 1265-1278 (1980).

34. Wit, J. C., de Nooijer, L. J., Wolthers, M. \& Reichart, G. J. A novel salinity proxy based on Na incorporation into forminiferal calcite. Biogeosciences 10, 6375-6387 (2013).

35. Swart, P. K. The strontium, magnesium, and sodium composition of recent scleractinian coral skeletons as standards for paleoenvironmental analysis. Palaeogeogr. Palaeoclim. Palaeoecol. 34, 115-136 (1981).

36. Mitsuguchi, T., Uchida, T. \& Matsumoto, E. Na/Ca variability in coral skeletons. Geochem. J. 44, 261-273 (2010).

37. Mitsuguchi, T., Uchida, T., Matsumoto, E., Isdale, P. J. \& Kawana, T. Variations in $\mathrm{Mg} / \mathrm{Ca}, \mathrm{Na} / \mathrm{Ca}$, and $\mathrm{Sr} / \mathrm{Ca}$ ratios of coral skeletons with chemical treatments: Implications for carbonate geochemistry. Geochim. Cosmochim. Acta. 65 , 2865-2874 (2001).

38. Okumura, M. \& Kitano, Y. Coprecipitation of alkali metal ions with calcium carbonate. Geochim. Cosmochim. Acta 50, 49-58 (1986).

39. Versteegh, E. A. A., Gillikin, D. P. \& Dehairs, F. Analysis of $\delta^{15} \mathrm{~N}$ values in mollusk shell organic matrix by EA-IRMS without acidification: an evaluation and effects of long-term preservation. Rapid Comm. Mass Spec. 25, 675-680 (2011).

\section{Acknowledgments}

We thank Matthew Winnick (UC Stanford), David Kesler (Rhodes College), David Goodwin (Denison University), and Kelsey Smith for assistance collecting the shells and preliminary analyses on these shells as well as Mary Ann Cunningham, Kirsten Menking, Stuart Belli and the whole Casperkill Watershed Group at Vassar College (http://www. dutchesswatersheds.org) for water sampling and analysis. Diarmaid O'Foighil of the University of Michigan Museum of Zoology generously allowed us to use two mussel valves collected from the Casperkill in 1877. Colby Howland and Nick Weidhaas helped drill the Ck-1 shell for oxygen-isotope ratio samples at Union College. Anouk Verheyden provided useful comments on an earlier draft of this manuscript. This work was funded by the Collins Fund for Environmental Research, Vassar College, the Mellon Foundation (at Vassar and Union Colleges), and the Union College Geology Department. The U.S. National Science Foundation funded Vassar College's Dionex IC (NSF-MRI\#0722813) and Union College's Perkin Elmer ICP-MS (NSF-CCLI \#9952410), CETAC LSX-213 (NSF-MRI \#1039832), and isotope ratio mass spectrometer and peripherals (NSF-MRI \#1229258).

\section{Author contributions}

D.P.G. designed the research and conducted the field sampling, D.D.O. analyzed the samples, D.D.O. and D.P.G. both drafted the manuscript.

\section{Additional information}

Competing financial interests: The authors declare no competing financial interests.

How to cite this article: O'Neil, D.D. \& Gillikin, D.P. Do freshwater mussel shells record road-salt pollution?. Sci. Rep. 4, 7168; DOI:10.1038/srep07168 (2014)

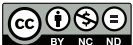

This work is licensed under a Creative Commons Attribution-NonCommercialNoDerivs 4.0 International License. The images or other third party material in this article are included in the article's Creative Commons license, unless indicated otherwise in the credit line; if the material is not included under the Creative Commons license, users will need to obtain permission from the license holder in order to reproduce the material. To view a copy of this license, visit http:// creativecommons.org/licenses/by-nc-nd/4.0/ 